\title{
Myotonic Dystrophy in Quebec: Geographical Distribution and Concept of Genetic Homogeneity
}

\author{
Claude Laberge
}

\begin{abstract}
The geographical distribution relative to place of residence of patients with myotonic dystrophy (MD) and admitted to a Quebec hospital during a five year period (1980-1984) is presented and discussed. The sample consists of 72 males and 68 females of varying ages over 10 years. Analysis of the data shows a North Shore distribution of patients in a cline from Saguenay-Lac-St-Jean, through Québec City and to Montréal. However, a low prevalence is apparent on the South Shore, east of Québec City, for which an historical and genealogical explanation are discussed. This geographic distribution favours the hypothesis of genetic homogeneity for the MD gene in the Québec population. A stronger second argument comes from genealogical studies of 10 families sampled from the Chicoutimi Muscular Dystrophy Clinic. Genealogical paths traced to ancestors who founded Charlevoix for these 10 families go back to a cluster of 25 founders, one of whom must have been the carrier of the MD gene. The probative third argument for genetic homogeneity comes from the allellic distribution of the apolipoprotein E (ApoE) gene in the Québec City, Saguenay and in families with MD. The ApoE locus is on chromosome 19 and closely linked to MD. In MD-affected individuals there is a linkage disequilibrium for the $\varepsilon 4$ allelle while non-MD members of these families show allellic frequencies not differing significantly from the control population. This suggests that the gene that is carried by all MD patients (at least in Northeast Québec) came through a "founder effect" and was carried in -cis on the chromosome 19 of the first carrier. Consequences of this genic homogeneity in relation to studies of penetrance and phenotypic variation in clinical expressivity are discussed.
\end{abstract}

RÉSUMÉ: Dystrophie myotonique in Québec: distribution géographique et concept d'homogénéité génétique La distribution géographique des lieux de résidence pour les patients atteints de dystrophie myotonique (DM) et admis dans les hôpitaux du Québec sur une période de cinq ans (1980-1984) est présentée et discutée. L'échantillon comprenait 72 hommes et 68 femmes d'âge variable de plus de 10 ans. L'analyse des données montre une distribution des patients selon un gradient qui va du Saguenay-Lac-St-Jean vers Montréal en passant par la ville de Québec sur la Côte Nord du St-Laurent. Une faible prévalence est cependant notée sur la Rive-Sud à l'est de Québec pour laquelle des explications historiques et généalogiques sont présentées. Cette distribution géographique suggère un premier argument pour supporter l'hypohèse d'homogénéité génétique du gène DM dans la population du Québec. Un deuxième argument, plus fort, vient de l'étude des généalogies de 10 familles sélectionnées dans la liste de la Clinique de Dystrophie Musculaire de Chicoutimi. Les liens généalogiques remontant aux ancêtres fondateurs de Charlevoix pour ces 10 familles aboutissent à une aggrégation de 25 fondateurs, dont un d'entre eux se devait d'être porteur du gène DM. Le troisième argument pour l'homogénéité génétique est le plus probant. Il découle de l'analyse de la distribution des allèlles de l'apolipoprotéine E (ApoE) dans les populations de Québec, du Saguenay et dans les familles avec DM. Le locus ApoE est situé sur le chromosome 19 et est en linkage étroit avec DM. Chez les individus atteints de DM il y a un déséquilibre de linkage pour l'allèlle $\varepsilon 4$ alors que chez les membres non-DM de ces familles les fréquences allélliques ne diffèrent pas d'une façon significative des fréquences de la population témoin. Ceci suggère que le gène présent chez tous les patients (du moins dans l'est du Québec) s'est distribué selon un «effet fondateur» et qu'il était originellement porté en -cis sur le chromosome 19 du premier porteur. Les conséquences de cette homogénéité génique en rapport avec des études de pénétrance et de variations phénotypiques d'expression clinique sont discutées.

Can. J. Neurol. Sci. 1989; 16:123-128

Preliminary data on the geographical distribution of Myotonic dystrophy (MD) in the Province of Québec are presented. The residences of patients hospitalized with a diagnosis of this disease between 1980 and 1984 are plotted on a map of the province. Based on a sample of families from the Muscular Dystrophy Clinic in Chicoutimi, genealogical and biochemical data are presented to support the concepts of genetic homogene- ity in the population of Lac-St-Jean - Chicoutimi and Charlevoix areas.

These introductory data are presented to serve as background information for the integration of information presented at this Symposium of more specific aspects of the disease such as clinical expression, linkage data, and socio-medical aspects in Northeastern Québec. 


\section{Materials AND Methods}

\section{Residence at the Time of Hospitalisation}

Non-nominative information on all patients admitted to Québec hospitals between January 1, 1980 and December 31, 1984 was obtained from the Research Services of the Québec Ministry of Health and Social Services. The data consisted of the date of birth of the patient, sex, the code number of the municipality of residence, the date of admission, and the code number of the hospital. With this information, it was possible to calculate single individuals with numerous hospital admissions (assuming that over the 4 year period, a patient with a diagnosis of MD would be unlikely to change his/her area of residence). It was also possible to calculate age and sex distributions according to the first available hospital admission in this specific sample size.

Because MD is mixed with paramyotonia congenita and myotonia congenita in the classification code \#359.2 of WHO International Classification of Diseases, ${ }^{1}$ all patients under the age of 10 years were deleted from the sample. Final geographic distribution of residence for 140 individual patients were plotted on a map of the province and is shown in Figure 1.

\section{Genetic Homogeneity in the Northeast of Québec}

Eleven informative families were selected for linkage studies. Attribution of the phenotype to chromosome 19 was necessary to demonstrate that the MD disease in this given population was the same as the one reported elsewhere and that we were not dealing with a phenocopy. The results of these linkage studies are presented elsewhere in this Symposium ${ }^{2}$ but they are here used as a basis for discussing the genetic homogeneity and the founder effect of MD for this region.

Dealing with classical MD as defined in this population by syntenic and linkage assignment to chromosome 19, we selected 10 families to establish a genealogical link between them, and to calculate the number of paths back to founding ancestors who settled in the Charlevoix area from France at the end of the 17 th and the beginning of the 18th centuries. Genealogies were first traced back to the time of colonization of the SaguenayLac-St-Jean area in the 1850's using the Chicoutimi database of SOREP, and then completed up to the time of the first settlements in Charlevoix using available marital repertories. ${ }^{3}$ Demographic, geographic and historic information on the original settlers were obtained from specialized dictionaries. ${ }^{4}$

Apolipoprotein E (ApoE) polymorphism typing was carried out in families with MD and on Red Cross samples from the Saguenay area, 5 and gene frequencies were calculated for this tri-allellic system.

\section{Results}

The geographical distribution of residence at the time of first admission to hospital for individuals presenting a \#359.2 diagnosis and presumed to be MD is shown on Figure 1. In relation

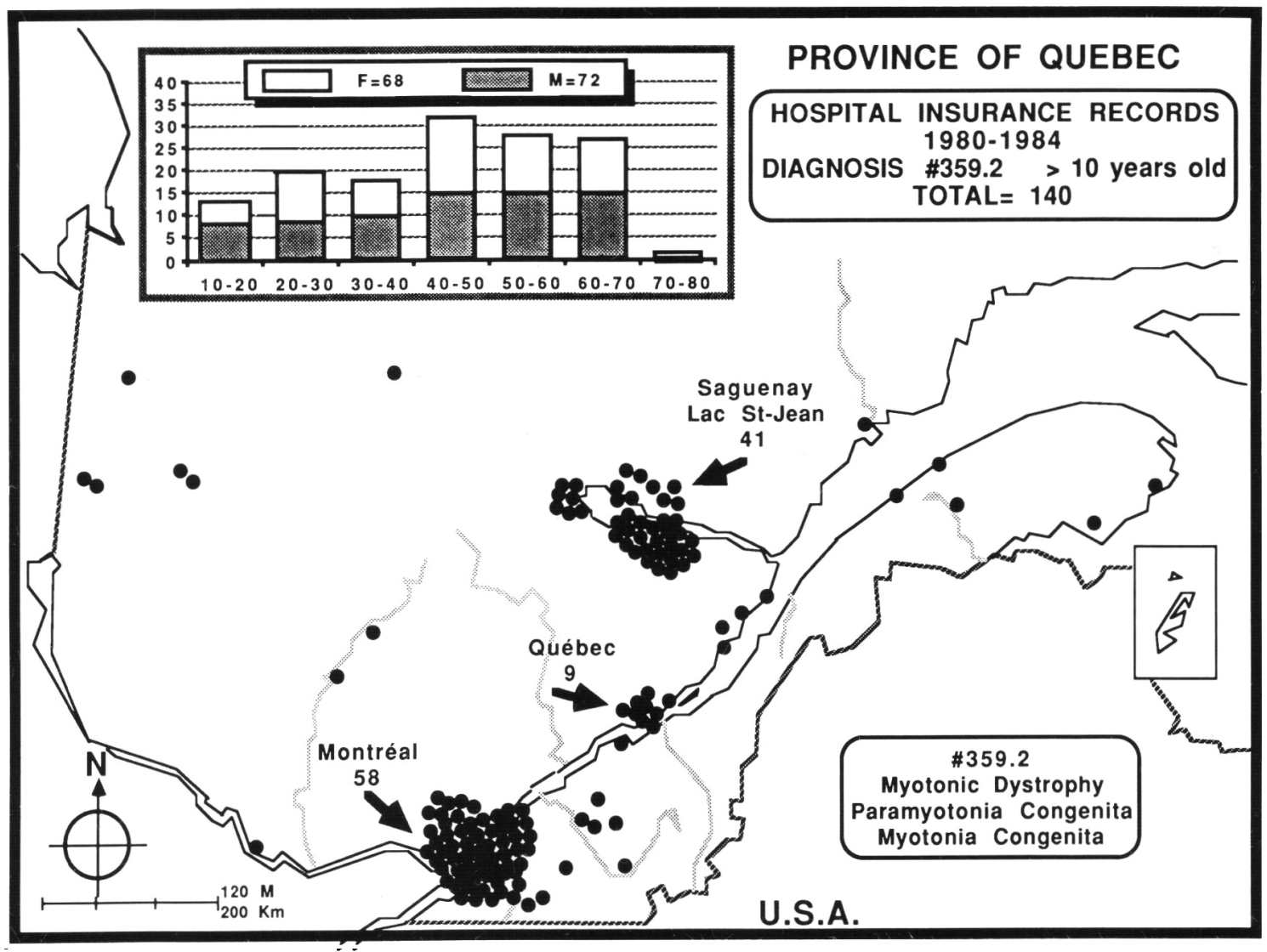

Figure 1 - Geographical distribution of the place of residence of 140 separate individuals hospitalized during a five-year period with a diagnosis of presumed Myotonic dystrophy. In cases of multiple hospitalizations, every effort with the non-nominative data available has been taken to plot only one such event. Note the heavy distribution on the North Shore of the St-Lawrence River and the relative scarcity of dots on the eastern South Shore. 
to the population density in the province, clustering of dots in the greater Montréal area is expected, since about half the population of Québec resides there. However, the high clustering in the Saguenay-Lac-St-Jean area is unexpected. It does, however, reflect the high prevalence that has been reported in this regional population from previous medical screening studies. Figure 1 also shows that the MD phenotype is present in most of the territory of the province, although there is a suggestion that its prevalence may be lower on the South shore, east of Québec City.

The insert shows that the sex ratio amongst the 140 patients retained for the study ( 72 males/68 females) is consistent with the expected $1: 1$ for an autosomal dominant phenotype. From ages 10 to 80 , the proportions in each age group do not seem to differ from the expected age pyramid of the general population presumed to have used hospitalization insurance during that 5year period.

Figure 2 shows the 11 informative families that were the basis for linkage studies. Ten of these (Family \#053 excluded) were chosen for genealogical studies.

Only 25 patronymes are represented as ancestral and as having at least one path per family leading back to a founding couple who migrated from France. These names are those of male and female ancestors of the founding couple. These patronymes and the number of paths back to each ancestor for each family is given in Table 1 where patronymes are classified by descending frequencies over all the pedigrees studied. Underlined names define an origin in France from a small lower-Normandy area called Perche in the 17th century. Twelve out of 25 ancestors came from that region and they represent $32.4 \%$ of all patronymes found in the ancestry of these 10 families, including those that were not common to all 10 families. These other ancestors came from the general area of Northwestern France. The last column represents the percentage of appearance of each ancestral name in the lineage of these 10 families over all the paths and of all ancestral patronymes being represented at least once and is calculated on the total of occurrence $[\Sigma(10 \mathrm{~F})]$.

In these 10 families, a total of 2,557 paths to separate founding ancestors could be identified. A total of $22.4 \%$ of genealogical paths from the Saguenay-Lac-St-Jean did not lead back to Charlevoix, which give an estimate of $77.6 \%$ for Charlevoix's contribution to the Saguenay's "gene pool" of the present-day population in which these MD families were sampled. This is in accordance with historical data based on other measurements. ${ }^{6}$ The 25 ancestors common to all 10 proband families, represent 1,497 such paths or $58.5 \%$ of the total.

Figure 3 graphically depicts in a simplified manner the type of interconnected ancestry of these families, using the shortest genealogical paths for each to common ancestors. The example chosen was Family \#029, surveyed at the time of the population screening. The manual method consists of constructing each genealogy, of absorbing each on the previous one (a "genealogical blot"), and retaining only those ancestors who remained at the end of each pass. Then, to graphically illustrate the cluster-

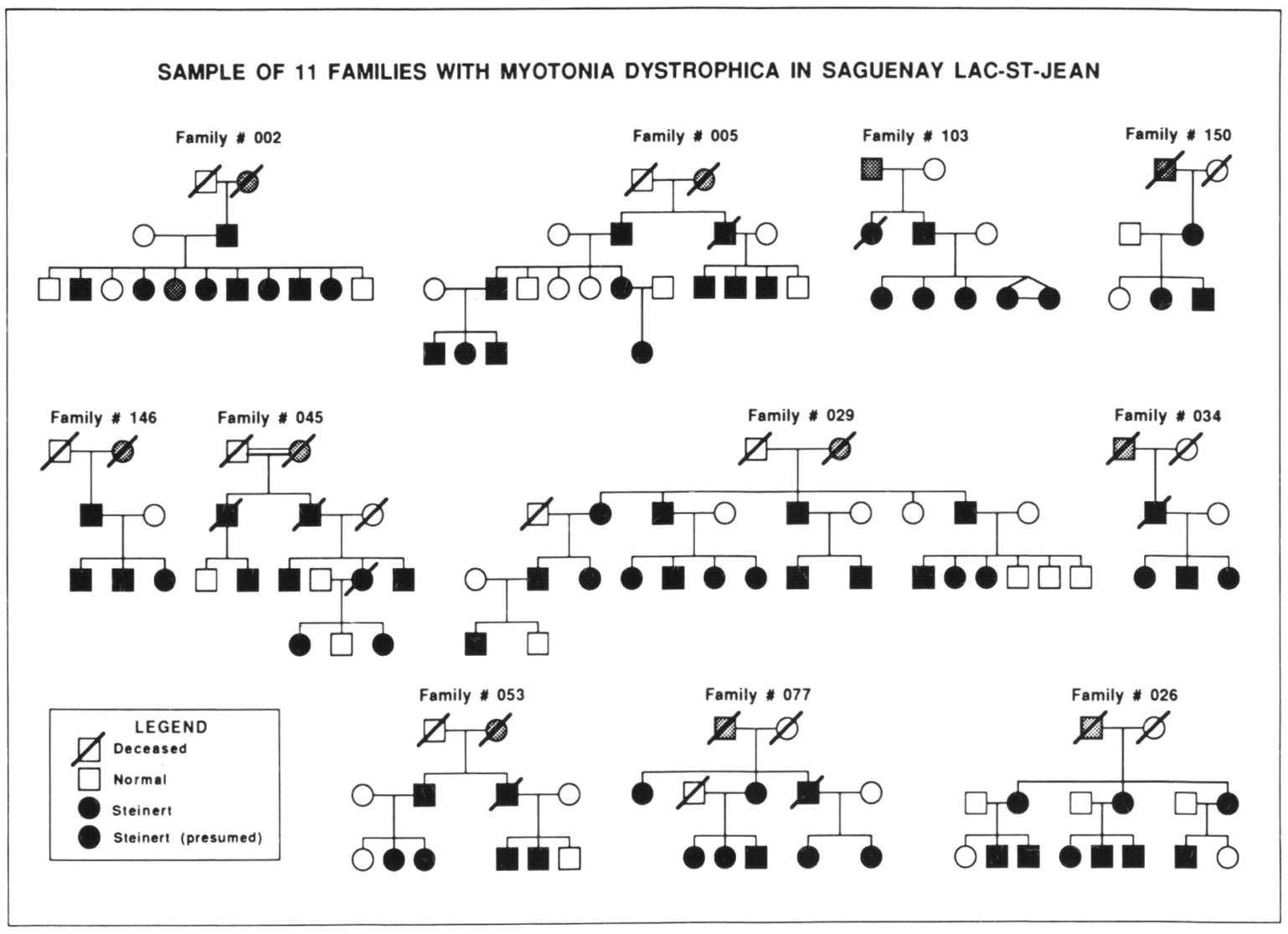

Figure 2-Pedigrees of 11 families sampled from the roster of the Chicoutimi Muscular Dystrophy Clinic showing large sizes and the classical autosomal dominant segregation pattern. 
ing, each pedigree is reviewed to draw generation lines to each of those common ancestors for each family. In the present case, this approach has been applied to the 25 common ancestors for the 10 families selected. The impression is strong that each family should reach back to a tightly knitted and interrelated group of Charlevoix ancestry (generations III to VIII in Figure 3), in which anyone could have been the founder-carrier for the gene of $\mathrm{MD}$ in the population. The high prevalence of $\mathrm{MD}$ in the Saguenay-Lac-St-Jean population and the obligated consanguinity of the isolated small population in Charlevoix in the first few founding generations preclude the finding of clear and linear paths to a single common ancestral couple. Any appropriation of founder-effect would have to be a probability based on frequency of occurrence through all families' ancestry affected with MD. Only complete computer analysis could provide these differential weights.

The gene frequencies for alleles at ApoE locus attributed to chromosome 19 in man are given in Table 2. The frequencies for Europe and the USA, ${ }^{7}$ for the regional population around Québec City and in the Saguenay are compared to frequencies determined for patients with MD and their non-MD relatives from the Saguenay MD roster. The frequencies of $\varepsilon 4, \varepsilon 3$ and $\varepsilon 2$ in non-MD members do not significantly differ from those obtained from the random Red Cross sample from the same area. However, the frequency of $\varepsilon 4$ in MD family members shows a three-fold increase, suggesting a strong linkage disequilibrium $\varepsilon 4-\mathrm{MD}$ and the high probability of a founder effect.
The gene for MD would have been introduced into the population on chromosome 19, carrying the $\varepsilon 4$ allele of ApoE and, due to the close linkage between the two genes, would have remained in -cis for generations.

\section{Discussion}

The geographic distribution of patients hospitalized with a diagnosis presumed to be MD shows that the disease is prevalent along the St-Lawrence River from the Saguenay and Charlevoix regions through Québec to Montréal and the Sherbrooke area.

In the South Shore east of Québec and toward the Gaspé Peninsula there is a remarkably low prevalence of MD. This may be due to artifacts of the sampling method, if there is a tendency not to hospitalize these patients in the medical practice of this area. However, even without knowing the natural history or justification for such hospitalizations in the rest of the province, it is difficult to imagine such an inconsistent practice in the South Shore area. An hypothesis which could be tested with further screening studies is that the prevalence is really low in this area, consistent with a founder effect in Charlevoix for most of MD cases in the province. The South Shore ancestry differs from that of Charlevoix, and migration patterns from Charlevoix are almost exclusively from there to Saguenay (accounting for about $80 \%$ of the gene pool there) and not to the South Shore. The MD markers and corresponding haplotypes

Table 1: Patronymes of the 25 Common Ancestors to the 10 Selected Families

\begin{tabular}{|c|c|c|c|c|c|c|c|c|c|c|c|c|}
\hline \multirow[b]{2}{*}{ Patronymes } & \multicolumn{10}{|c|}{10 Families with DMS (Saguenay) } & \multirow[b]{2}{*}{$\sum(10 F)$} & \multirow[b]{2}{*}{$\%(10 \mathrm{~F})$} \\
\hline & $\# 29$ & \#45 & \#146 & \#05 & \#34 & $\# 26$ & $\# 77$ & $\# 02$ & $\# 150$ & $\# 103$ & & \\
\hline TREMBLAY & 11 & 17 & 28 & 12 & 13 & 21 & 21 & 7 & 17 & 20 & 167 & 6.53 \\
\hline GAGNE & 10 & 15 & 16 & 10 & 10 & 16 & 18 & 6 & 11 & 17 & 129 & 5.04 \\
\hline MARTIN & 4 & 17 & 17 & 6 & 9 & 16 & 15 & 3 & 10 & 9 & 106 & 4.15 \\
\hline RACINE & 4 & 16 & 14 & 6 & 8 & 14 & 13 & 3 & 9 & 9 & 96 & 3.75 \\
\hline SIMARD & 7 & 14 & 14 & 6 & 7 & 11 & 13 & 3 & 7 & 8 & 90 & 3.52 \\
\hline BOUCHARD & 8 & 13 & 11 & 6 & 6 & 6 & 12 & 4 & 7 & 9 & 82 & 3.21 \\
\hline GUYON & 7 & 6 & 14 & 6 & 7 & 9 & 11 & 4 & 10 & 6 & 80 & 3.13 \\
\hline PARADIS & 6 & 6 & 11 & 6 & 6 & 9 & 11 & 3 & 8 & 5 & 71 & 2.78 \\
\hline ROUSSIN & 6 & 6 & 11 & 6 & 6 & 9 & 11 & 3 & 8 & 5 & 71 & 2.78 \\
\hline GAGNON & 4 & 15 & 9 & 3 & 3 & 9 & 4 & 3 & 3 & 3 & 56 & 2.19 \\
\hline$\overline{\text { CARON }}$ & 2 & 3 & 9 & 3 & 5 & 7 & 8 & 2 & 3 & 9 & 51 & 1.99 \\
\hline GARGOTTINE & 3 & 3 & 10 & 4 & 5 & 6 & 3 & 1 & 4 & 8 & 47 & 1.84 \\
\hline PERRON & 3 & 3 & 10 & 4 & 5 & 6 & 3 & 1 & 4 & 8 & 47 & 1.84 \\
\hline PAQUET & 4 & 2 & 4 & 3 & 2 & 10 & 7 & 2 & 3 & 6 & 43 & 1.68 \\
\hline CAUCHON & 4 & 6 & 7 & 2 & 3 & 5 & 6 & 1 & 3 & 4 & 41 & 1.60 \\
\hline GODIN & 2 & 8 & 6 & 1 & 2 & 7 & 5 & 3 & 3 & 3 & 40 & 1.56 \\
\hline DODIER & 1 & 3 & 4 & 3 & 4 & 5 & 7 & 2 & 2 & 7 & 38 & 1.49 \\
\hline FORTIN & 3 & 2 & 6 & 3 & 1 & 9 & 6 & 4 & 1 & 3 & 38 & 1.49 \\
\hline$\overline{\text { GAMACHE }}$ & 3 & 2 & 6 & 3 & 1 & 9 & 6 & 4 & 1 & 3 & 38 & 1.49 \\
\hline LAVOIE & 2 & 7 & 6 & 1 & 2 & 5 & 5 & 3 & 3 & 3 & 37 & 1.45 \\
\hline BIVILLE & 3 & 2 & 4 & 2 & $\overline{1}$ & 9 & 6 & 2 & 2 & 3 & 34 & 1.33 \\
\hline DROUIN & 4 & 2 & 10 & 1 & 2 & 2 & 4 & 1 & 2 & 3 & 31 & 1.21 \\
\hline CLOUTIER & l & 1 & 8 & 1 & 2 & 3 & 1 & 3 & 2 & 5 & 27 & 1.06 \\
\hline$\overline{\text { PELLETIER }}$ & 2 & 2 & 5 & 1 & 1 & 1 & 3 & 2 & 2 & 2 & 21 & 0.82 \\
\hline AYMARD & 1 & 1 & 7 & 1 & 2 & 1 & 1 & 1 & 1 & 0 & 16 & 0.63 \\
\hline
\end{tabular}

The method used was sequential "genealogical blotting" as explained in the text. Underlined patronymes originate from the Perche region in France, a small area south of Normandy and north of Le Mans, just above the Loire River axis from Paris to LaRochelle (one of two major seaports for migration to Canada during the French Regime from 1605 to 1759). Numbers in each family's column represent the number of paths per family pedigree going back to the given ancestor. The sum of paths to common ancestors for the aggregated 10 families and the percentage of these summated paths over the total number of 2,557 for all ancestral paths (common to all 10 families or unique to any one of these 10 ) are also given. These 25 patronymes of common ancestors represent 1,497 occurrences of $58.5 \%$ of all links to founding ancestors for these 10 families. 


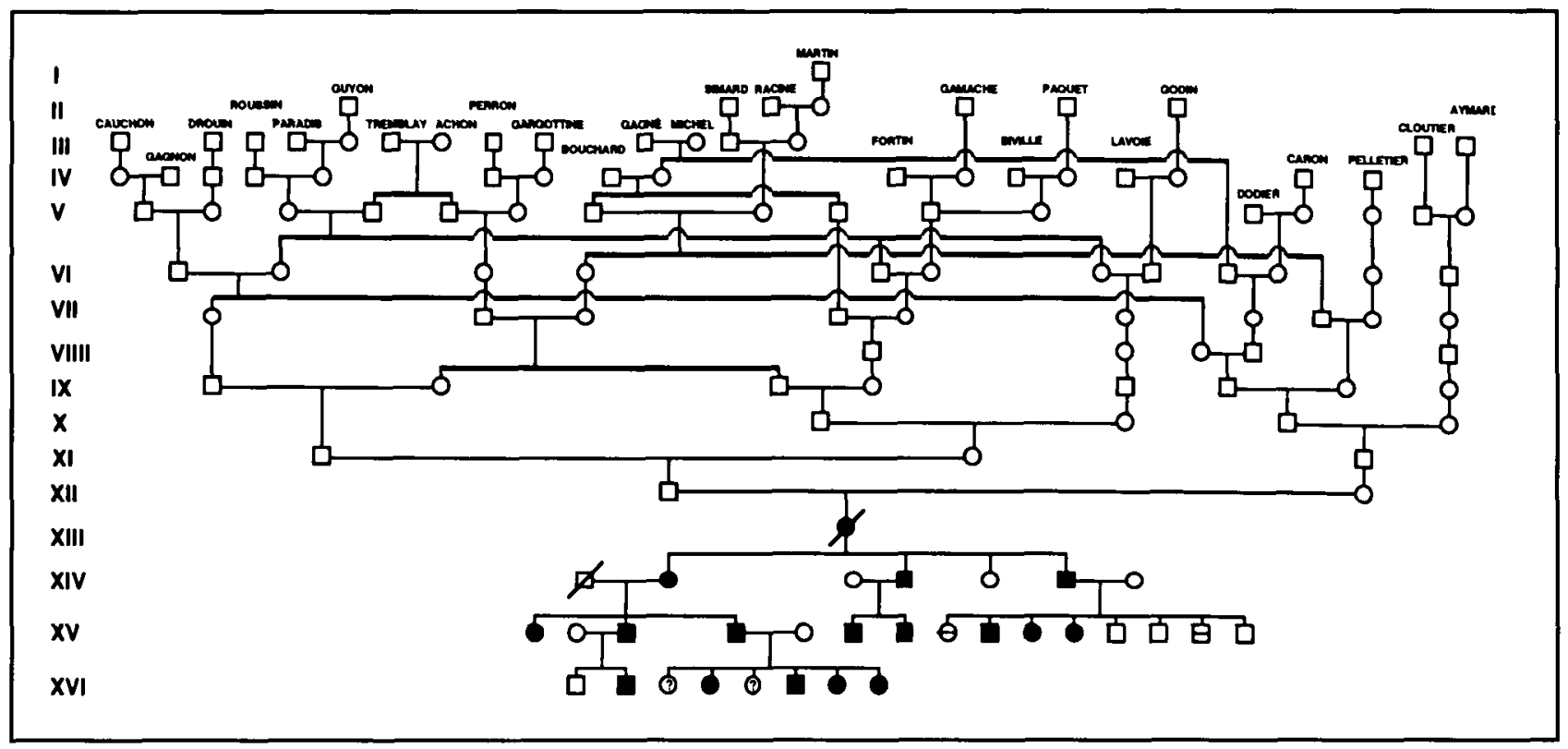

Figure 3 - Outline of simplified genealogical interrelations of 10 families from Figure 2. For purposes of demonstration, the most sinplified and direct paths to each of 25 common ancestors identified in the genealogical search to Charlevoix are presented for Family \#029. The central part of the pedigree for generations $V$ to XI suggests a mixed and inbred nature of the Charlevoix population before the mid-19th century when migration to Saguenay-Lac-St-Jean occurred to found the present population from which 10 families with MD were selected for this study.

on chromosome 19 should be specific to the Northeastern Shore and should be present in the great majority of French Canadians with myotonic dystrophy.

The data on the residence of patients is, however, only a suggestive argument and only supports a genetic homogeneity of the mutation present in the French Canadian population of Québec, probably because they are descendents of or related to founders in Québec and/or Charlevoix in the second half of the 17th century who arrived from Northwestern France.

The second argument in favor of genetic homogeneity is historical and genealogical. Patients from a sampling of families followed at the Chicoutimi Muscular Dystrophy Clinic all related to the founding stock of Charlevoix for at least $75 \%$ of their genealogical paths. Before the 1850's, the time of migration to colonize the Saguenay-Lac-St-Jean area, the gene pool was clearly in Charlevoix, though it is difficult with manual methods and restricted sample size to assign personal statistical weights to each ancestor in the 25 that are common to all ten proband families. The isolated population of Charlevoix at that early time was quite consanguineous, mainly secondary to random inbreeding originating from malthusian population growth, restricted land availability for farming, occupancy of all possible such lands, and limited immigration. The image that comes to mind looking at the sketchy pedigree of Figure 3 is that genes from early founders "trickled" in the population of Charlevoix at the beginning but soon (in a very few generations) went through a "watermill" that blended and spread them uniformly very rapidly within the descendents. A late onset dominant phenotype not significantly affecting early fertility would rapidly disseminate the gene.

The third argument for genetic homogeneity is of a biological nature. The ApoE polymorphisms show a cline toward the east from Québec to Saguenay and necessarily through
Table 2: Allelic Frequencies for the Locus Apolipoprotein $\mathbf{E}$ (ApoE) Situated on Chromosome 19

\begin{tabular}{cccccc}
\hline \hline & Europe/USA & Quebec & Saguenay & Non-MD & $\overline{\mathbf{M D}}$ \\
\hline$\varepsilon 4$ & 0.144 & 0.109 & 0.144 & 0.160 & 0.410 \\
$\varepsilon 3$ & 0.752 & 0.728 & 0.649 & 0.610 & 0.440 \\
$\varepsilon 2$ & 0.104 & 0.173 & 0.208 & 0.230 & 0.140 \\
\hline
\end{tabular}

The cline from Québec to Saguenay (and non-MD individuals in proband families) support the notion of genetic drift and genetic isolate in the latter with an increase in the $\varepsilon 4$ isomorph frequency. In MDaffected patients, the frequency for this allele $\varepsilon 4$ is increased by almost three-fold indicating linkage disequilibrium. The MD gene must have been introduced by a founding ancestor carrying the chromosome 19 $\mathrm{MD}-\varepsilon 4$. Since the linkage between these two loci is close enough, there has not been enough time in about 15 generations for them to come back to control population gene frequency equilibrium. These data support the hypothesis of genic homogeneity for MD in this Saguenay population.

Charlevoix. The Québec area is significantly different from Europe and the USA. The Saguenay population shows more genetic drift, but the non-MD members of the Saguenay-Lac-StJean families are not deviant from their own control population. Only the MD-affected persons in these families show a marked deviation, mainly at the expense of an increase in the allele frequency of $\varepsilon 4$. This linkage disequilibrium leads to the hypothesis that some 12 or 13 generations earlier, the MD gene was introduced into the population from a founder carrying the $\varepsilon 4$ allele closely linked and in -cis with the MD gene. The study of other close RFLP markers should yield a chromosomal haplo- 
type for the MD chromosome in this population that could be very useful in risk prediction, even in truncated families.

All of these epidemiological, historical, genealogical, and biological arguments, added to the linkage study reported elsewhere in this symposium, make the hypothesis of molecular homogeneity of the MD a tenable one, at least in SaguenayLac-St-Jean and Charlevoix, and probably also in the Québec City area. Further RFLP markers should help to construct a haplotype map that will validate this hypothesis.

Once molecular and genic homogeneity are proven, as expected, it may become an important tool in isolating the putative gene from the sheer force of great numbers of patients in "population genetics". It is potentially the most powerful basis for the study of phenotypic expressivity, the testing of the Penrose hypothesis of modulation by normal -trans alleles, and the deciphering of the maternal effect on MD-affected newborns. It must be remembered that the "gene is not the disease". Knowledge of variation of expression is a necessary answer to genetic counselling questions about prognosis and, eventually, about treatment.

\section{Conclusion}

Data from three complementary studies are presented to propose genic homogeneity for the MD gene in Québec. It is expected that most if not all, affected French Canadians are carriers by descent of an identical mutation at the MD locus on chromosome 19.

Geographical distribution of place of residence for 140 patients hospitalized with a diagnosis of MD for a five-year period (1980-1984) show an East-West cline of frequencies from Lac-St-Jean to Montréal along the St-Lawrence River, seemingly sparing the South Shore east of Québec. These data seem to suggest an origin for the founding ancestor in Charlevoix and demic attribution for the majority of patients in the province. If this hypothesis is correct, prevention strategies are dependent upon isolating specific "Charlevoix" gene markers (constituting diagnostic haplotypes) that eventually could be identified in individuals at risk.

From historical and genealogical data on a sample of 10 families, it is quite evident that the ancestry $( \pm 75 \%)$ goes back to Charlevoix from early 19 th to late 17 th centuries. The original "founder" is a member of a tightly mixed inbred isolate, but it is impossible to assign complete probability to any one in par- ticular, limited by the small sample size of 10 families. Genealogical studies of all MD carriers in the province will eventually identify such a common ancestor as well as the corresponding founder's area of origin, probably in Northwestern France in the 17 th century.

Biological data on the polymorphism of ApoE in the control population and in affected and non-affected individuals in MD families support an haplotypic genic homogeneity in the Saguenay-Lac-St-Jean population. Linkage disequilibrium for ApoE allele $\varepsilon 4$ suggests that the founder's chromosome had at least a MD- $\varepsilon 4$ chromosome. Polymorphic RFLP "flanking" markers, short of a specific gene probe, should become diagnostic for the presence of the mutation in individual genomes.

The elucidation of the late-onset diagnosis and the variable phenotypic expression of this dominant disease may arise from clinical research on a large number of patients and "at-risk" individuals carrying the same mutant gene, in an otherwise restricted genetic isolate situation where choices of polymorphism are limited by genetic drift. The population of MD patients in the Northeast and probably in the whole Province of Québec will be useful for understanding the genetic basis for the natural history and the variability of expression of this disease, once the problem of penetrance is resolved by the molecular biological deciphering of the genic phenotype.

\section{REFERENCES}

1. Organisation Mondiale de la Santé. Classification Internationale des Maladies. Revision 9, 1975. Genève, 1977.

2. Thibault MC, Mathieu J, Moorjani S, et al. Myotonic dystrophy: linkage with apolipoprotein $\mathrm{E}$ and estimation of the gene carrier status with genetic markers. Can J Neur Sci 1989, this issue.

3. Girard Fr Éloi. Receuil de Généalogies des Comtés de Charlevoix et Saguenay. La Malbaie 1941; 575.

4. Jetté, R. Dictionnaire généalogique des familles canadiennesfrançaises. Des origines à 1730. Presses de l'Université de Montréal 1983; 1325.

5. Moorjani S, Morissette J, Laberge C, et al. ApoE polymorphism in Québec population. Clin and Invest Med 1987; 10: 4, B51.

6. Bouchard G, Morissette J, Kouladjian K. La statistique agrégée des patronymes du Saguenay et de Charlevoix comme indicateurs de la structure de la population aux XIXe et XXe siècles. Cahiers québécois de démographie 1987; 61: 67-98.

7. Sing CE, Davignon J. Role of apolipoprotein E polymorphism in determining normal plasma lipid and lipoprotein variation. Am J Hum Genet 1985; 37: 268-285. 